\title{
Analysis on Fundamental of Macroeconomy Factors on Banking Performance and its Implications to Third Party Funds: A Case Study of Indonesia
}

\author{
Iqbal Firdausi \\ STIE Indonesia, Banjarmasin, Indonesia
}

\begin{abstract}
This study aimed to describe fundamental of macroeconomy, performance of banking and third party funds, analyze impact of fundamental of macroeconomy on bank performance, analyze effect of bank performance to deposit, analyze impact of fundamental of macroeconomy to deposit also analyze effect of fundamental of macroeconomy of third party funds through banking performance. The type of this research is descriptive explanatory that describe causality through hypothesis testing. This study uses 4 banks for 11 years (series) i.e. 2004 to 2014, with combined model of data obtained as many as 132. The analysis technique used is descriptive analysis and Analysis of Structural Equation Modeling (SEM). The results showed that fundamental of macroeconomy affect bank performance; it does show that every event relating to inflation and BI rate in the real sector will affect banks' performance. Performance of banking industry affects third-party funds. In conditions, interest rates rise, it will suppress growth of third party funds (including assets) of banks, and vice versa if interest rates experienced a declining trend, bank deposits will increase. Fundamental of macroeconomy affect third-party funds.
\end{abstract}

Keywords: Fundamental of Macroeconomy, Performance of Banking, Third Party Funds.

\section{INTRODUCTION}

Macroeconomic stability is a fundamental factor to ensure sustainable economic growth (sustainable economic growth). In order to maintain macroeconomic stability, financial authority must strengthen resilience of domestic economy in any fluctuation that arise both from within and from abroad. This efforts are also accompanied by programs in implementation of development activities are required include steps to control inflation also keep stability exchange rate and low interest rates. Such efforts faced serious challenges, such as high prices of some food and international oil prices.

Indonesia's economic performance in 2012 was encouraging in the weakened and uncertainty world economy. Economic growth can be maintained at a sufficiently high level, namely $6.2 \%$, with inflation controlled at a low level (4.3\%) so that inflation target in range of $4.5 \pm 1 \%$. In condition export performance is declining, economic growth is more sustained by a strong domestic demand. This is supported by macroeconomic conditions and financial system that is conducive to allowing household sector and business sector perform better economic activity. In addition, strong domestic demand in the weak export performance caused imbalance in current account.

Improved economic stability supported by steps to strengthen financial sector to encourage economic activity grew faster. To improve performance and sustainability of financial sector as well as development funding sources, financial sector policy is geared to maintain resilience of financial services industry, increase in intermediation function of public funds, as well as development of financial sector safety net system. As a financial institution which has the largest financial intermediation function in Indonesia, national banking were directed to have more capability in encouraging development in various sectors through loan portfolio that evenly distributed throughout the country.

Banking is known as intermediary institutions between people whose excess liquidity with parties that require liquidity, both for business or consumption. To achieve these objectives, financial authority established interest rate mechanism. Interest rates on savings or deposit is required so that people want to save their money in banks, because then customers will receive returns in the form of interest on funds that the customer save.

One alternative to improve growth of real sector is provide widest opportunity to entrepreneurs at all levels to obtain additional capital, ie reduce lending rates. In order to manage interest rates of national banks, central bank of Indonesia using 
instruments for determining the reference interest rate, that is BI Rate. BI rate would then be a reference to determining interest rate of SBI and Interbank Money Market. SBI interest rate and interbank these will affect interest rates on deposits and loans in national banking system.

Bank of Indonesia is trying to achieve this goal by lowering BI rate gradually for example during 6 last months. As of November 2008 BI rate is still within range of 9.5\% (Indonesian Financial Statistics), and then in December lowered to 9:25\%. The decline continued until June BI rate at $7 \%$. The decline in BI rate is done to reduce the tight liquidity in business communities, in hope economy could grow better.

Performance of banking is expected to increase its contribution in economy, because of the role of banks is so large, it is important to ascertain that financial system and economy in a country is also running smoothly and efficiently. Banking performance can be affected by internal and external factors. Internal factors which may be referred to competitiveness of each bank, while external factors may include macroeconomic and financial condition of a country. The competitiveness of each bank may vary according to characteristics and distinctive advantages possessed. Under a conducive conditions, banking can provide a positive environment to development itself. Conversely, macroeconomic and financial conditions are less stable can affect market risk and credit risk of banks, which in turn may have an impact on bank performance. In general, macroeconomic variables that are often used as a determinant of banking performance of various lots of studies are national income or economic growth, inflation, and interest rates. In accordance with the functions of bank as a financial institution where their daily activities are engaged in finance, sources of funding can not be separated from the financial sector, to support activities of banks as lenders, must first raise funds so that from all of interest to improve banking performance.

\section{LITERATUR REVIEW}

\subsection{Banking Performance}

Bank's performance is very important as a tool to evaluate banks operations and determine a plan of management and strategic analysis. Banks have a role in economic growth. So if bank's performance is good, overall economy will also be good. Banking performance is a figure of achievements in bank's operations, both related to financial aspects, marketing, collection and disbursement of funds, technology and human resources (Rose, 2002: 138) [1]. Financial performance of bank is describing financial condition of banks in a given period both concerning aspects of fund raising and distribution of funds that are usually measured by indicators of capital adequacy, liquidity, and profitability of banks (Jumingan, 2006) [2].

Bank performance has two indicators and two key dimensions. Indicator of bank performance is an indicator of quality and quantity. Dimensions of bank performance is dimension of profitability and risk dimensions. To measure profitability can use ROA (return on assets) and ROE (return on equity) as a proxy, while to measure risk can be use LDR (loans-to-deposit ratio) and CAR (capital adequacy ratio) as a proxy (Rose, 2002: 138) [1].

\subsection{Fundamental of Macroeconomy}

Macroeconomics is study of behavior of the whole economy. Macroeconomic analysis covering long-term growth cycle of movement including total output, unemployment and inflation, money supply and budget deficit, also international finance and trade (Samuelson and Nordhaus, 2001: 78) [3]. This analysis is very useful to examine factors that affect company, consumers and society at a time.

Stiglitz and Walsh (2006: 153) stated that key objectives of macroeconomic policy, namely employment, economic growth, interest rates and price stability [4]. Availability of jobs to make sure everyone gets a decent job, ensure increased economic growth in living standards, and a low inflation rate stable facilitate future planning. Macroeconomics is constantly studying causes of slow growth, unemployment, interest rates and inflation. Measurement used to assess or estimate the key macroeconomic variables are numerous. Indicators are used as a proxy are exchange rate, inflation, and interest rates

\subsection{Third Party Funds}

Third party funds (savings) as defined in Banking Law No. 10 of 1998 on Banking is funds entrusted by the public to bank based on deposit agreement funds in the form of demand deposits, time deposits, certificates of deposit, savings, or other similar forms. According to Kashmir (2003: 64), third party funds are funds from broader community which is most important source of funds for banks operations [5]. It's also a measurement of bank success that able to finance its operations from this funding source. Third party funds under Suyanto (1999: 38) is third party deposits are in form of deposit some money in bank in form of Demand, Savings, Deposits, Current Account [6]. Third party funding requires a bank to run its operations. Dendawijaya (2009) defined third-party funds are funds in form of deposits from public [7]. It turns out biggest funding sources most relied upon by the bank (it can reach $80 \%-90 \%$ of all funds managed by the bank. Bank may utilize funds from third party to be placed on items that generate income for the bank, among them, is in the form of loans. Growth of third party funds will lead to credit growth, 
which in turn LDR will also increase. Source of these funds is the most important funding source for bank operations. According to Banking Act No. 10 of 1998 sources of funds are as follows:

1) Demand deposits are deposits which may be withdrawn at any time by check, giro, any forms of payment order or by overbooking.

2) Deposit is savings that only withdrawn at a certain time based on agreement with bank depositor.

3) Saving is saving that may only be withdrawn under certain conditions agreed upon, but it can not be withdrawn by check, bank draft, or other instrument that is equivalent to them.

\subsection{Hypothesis}

$\mathrm{H}_{1} \quad$ : Fundamental of macroeconomy affect to performance of banks.

$\mathrm{H}_{2}$ : performance of banks affect to third party funds.

$\mathrm{H}_{3}$ : Fundamental of macroeconomy affect to third party funds.

$\mathrm{H}_{4} \quad$ : Fundamental of macroeconomy affect to third party funds through performance of banks.

\section{RESEARCH METHOD}

\subsection{Conceptual Definition of Variables}

1) Fundamental of Macroeconomy

Fundamental of Macroeconomy are factors outside the company, but have an influence on increase or decrease of banks performance, both directly and indirectly. Macroeconomy that can directly affect performance of banking, among others:

a) Exchange Rate

Exchange Rate Rupiah to US Dollar is exchange rate of currency that is Rupiah to US Dollar. In this study, measurement used are: amount of Exchange Rate Rupiah to US Dollar at the close of trading of currencies in units rupiah each month during 2004 and 2014.

b) Inflation

Inflation is the change in inflation rate released by Bank of Indonesia in period January 1, 2004 - 31 December 2014 and calculated each month in form of percentage.

c) BI Rate

BI Rate is a reference interest rate set by Bank of Indonesia and announced to public as measured by interest rate per month during 2004 to 2014 in percentage.

2) Performance of Banking

Performance of Banking is financial condition of banks in 2004 through 2014 were observed by a ratio per month from banks corporate to Bank of Indonesia.

a) Capital Adequacy Ratio (CAR)

CAR is an assessment of capital aspect is intended to determine how or how much bank's capital is adequate to support the business.

b) Efficiency Ratio (ER)

Efficiency ratio is used to measure ability of bank management in controlling operating expenses to operating income.

c) Return On Assets

Return On Assets, indicate company's ability to generate profits with all company's assets.

d) Loan to Deposit Ratio (LDR)

LDR to measure the ability of the bank is able to pay off debts and reimburse depositors and can meet the demand of its proposed loan without a delay.

3) Third Party Funds

Public funds in the form of giro, deposits, and savings are reported by Bank of Indonesia in period 2004 - 2014, which is measured in rupiah. 


\subsection{Population and sample}

Population of this study was the whole banks corporate in Indonesia which in 2014 amounted to 4 banks consisting of: PT. Bank Negara Indonesia 46 (Persero), Tbk; PT. Bank Mandiri (Persero), Tbk; PT. Bank Rakyat Indonesia (Persero), Tbk and PT. Bank Tabungan Negara (Persero).

Sample of this study were all banks that are part of population. Thus, sampling method used is census method that is full sampling of as many as four banks with an 11-year study period from 2004 to 2014. Data were collected in a coherent time (time series) that is data arranged chronologically according to the time on a particular variable and cross section. In this case, data collected at a point of time, called data polling by combined models. This study uses combined model of data obtained as many as 132.

\subsection{Techniques of Data Analysis}

Data analysis techniques used in this research is descriptive analysis and Structural Equation Modeling (SEM).

\section{RESULTS AND DISCUSSION}

\subsection{Description of Research Variabels}

Table 1 consists of description of each variables

Tabel 1. Descriptive Statistic

\begin{tabular}{|l|c|c|c|c|c|}
\hline & $\mathbf{N}$ & Minimum & Maximum & Mean & Std. Deviation \\
\hline Exchange Rate & 132 & 8403 & 12410 & 9694.91 & 1020.351 \\
\hline Inflation & 132 & 2.41 & 18.38 & 7.2334 & 3.53546 \\
\hline BI Rate & 132 & 5.8 & 12.8 & 7.606 & 1.8788 \\
\hline CAR & 132 & 12.77 & 24.68 & 18.0550 & 2.92305 \\
\hline Efficiency Ratio & 132 & 66.16 & 174.97 & 90.5514 & 17.59221 \\
\hline ROA & 132 & -1.51 & 4.23 & 2.9345 & .84661 \\
\hline LDR & 132 & 40.4 & 89.8 & 70.554 & 13.5970 \\
\hline Giro & 132 & 58737 & 219555 & 117871.37 & 46319.284 \\
\hline Deposits & 132 & 124934 & 572294 & 267143.92 & 116326.406 \\
\hline Saving & 132 & 114811 & 566153 & 268216.92 & 130745.762 \\
\hline
\end{tabular}

Source: Data Processed

Based on table 1, it can be explained that minimum value of exchange rate of Rp 8403, a maximum of 12,410, mean value of 9694.91 with a standard deviation of 1020.351, this suggests that exchange rate is relatively stable. Inflation minimum value of 2.41, a maximum of 18.8 , a mean of 7.23 with a standard deviation of 3.53 . BI rate is minimum value of 5.8, a maximum of 12.8 , the mean value of 7.606 with a standard deviation of 1.8788 . CAR minimum value of 12.77 , a maximum of 24.68 , mean of 18.0550 and a standard deviation of 2.92305 , so that in healthy category. Efficiency ratio minimum value of 66.16 , a maximum of 174.97, a mean of 90.5514 and a standard deviation of 17.59221 , so that also in healthy category. ROA minimum value of -1.51 , a maximum of 4.23, a mean of 2.9345 with a standard deviation of 0.84661 , it shows that every USD 1 total assets earned a profit of Rp. 2.9345. LDR minimum value of 40.4, a maximum of 89.8, a mean of 70.554 with a standard deviation value of 13.5970 , so that in healthy category. Giro minimum value of 58 737, a maximum of 219555 , with a mean of 117,871.37 standard deviation value of 46319.284. Deposits minimum value of 124 934, a maximum of 572 294, with a mean of 267,143.92 standard deviation value of 116,326.406. Saving a minimum value of 114 811, a maximum of 566 153, a mean of 268,216.92 with a standard deviation value of $130,745.762$.

\subsection{Results of SEM Analysis}

1) Test of SEM assumptions

a) Normality Test

Normality test of data is done by observing CR value with multivariate. If critical value of ratio in multivariate be in interval 2.58 to 2.58 , it can be categorized data distributed normally. Based on the results of multivariate calculation CR value of 1.226 which is outside interval -2.58 to 2.58 , it is concluded multivariate normality assumptions are met. 
b) Outlier Test

Outlier test was conducted using Mahalanobis distances (Mahalanobis distance squared). If Mahalanobis distance squared is greater than value of chi-square $\mathrm{df}=$ the number of indicators and a significance level of 0.001 , then data is an outlier. Results of this test by Mahalanobis distance squared showed that statistically there are detected observations as outliers that are observations have greater distances mahalanobis chi square table $\mathrm{df}=8$ (the number of indicators), $\alpha=0.001$ ), namely 26.13, this results show that observation for 24 and 25 is an outlier, so these observations are eliminated.

2) Compliance Test Model (Goodness of Fit)

In accordance with literature review and research purposes, then developed the entire structural model as follows:

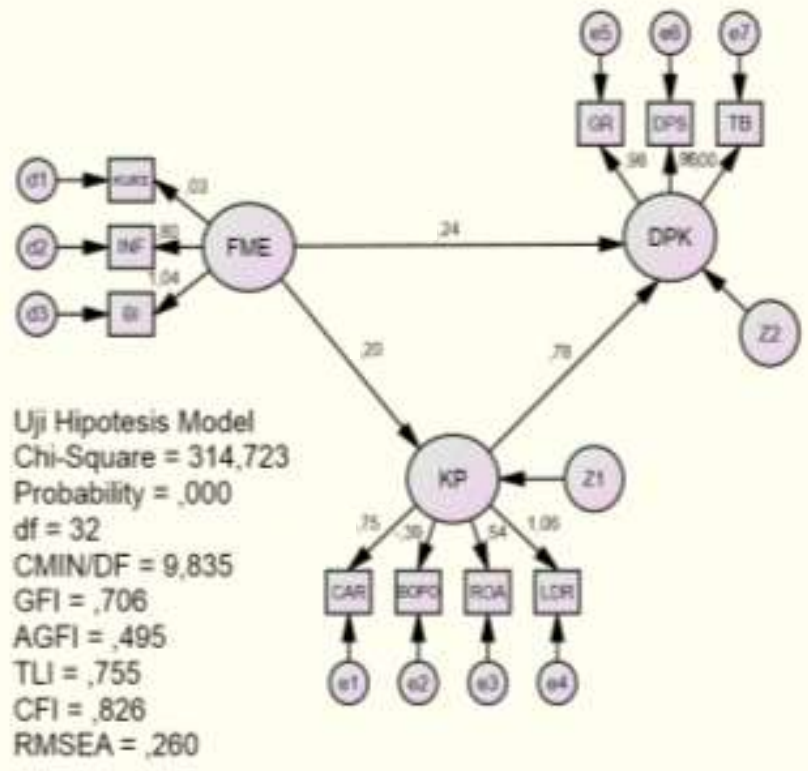

Figure 1. Previous Model

Source: Data Processed

Early models in Figure 2 is not worthy of representing data to be analyzed because it does not qualify goodness of fit indices recommended, it can be seen from suitability index model (goodness of fit) are presented in Table 1. Furthermore, values of this index compared with critical value (cut-off value) of each index. A good model is expected to have goodness off fit index greater than or equal to the critical value.

Table 2. Evaluation Criteria for Suitability Index of Initial Structural Model

\begin{tabular}{|l|c|c|c|}
\hline \multicolumn{1}{|c|}{ Criteria } & Critical Value & Result & Model Evaluation \\
\hline Chi-square $(\mathrm{df}=32)$ & 53.49 & 314.723 & Not so good \\
\hline Probabilities & $\geq 0.05$ & 0.000 & Not so good \\
\hline CMIN/DF & $\leq 2.00$ & 9.835 & Not so good \\
\hline RMSEA & $\leq 0.08$ & 0.260 & Not so good \\
\hline GFI & $\geq 0.90$ & 0.706 & Not so good \\
\hline AGFI & $\geq 0.90$ & 0.495 & Not so good \\
\hline CFI & $\geq 0.95$ & 0.826 & Not so good \\
\hline TLI & $\geq 0.95$ & 0.755 & Not so good \\
\hline
\end{tabular}

Source: Data Processed

Table 2 shows a summary of results obtained in analysis and recommended value to measure feasibility of the model. Results of feasibility model test at early structural model shows that no one has good category. Results of analysis conclude that model needs to be evaluated. Therefore it is necessary to reduce double correlated manifest with other manifest.

Based on Figure 2 can be explained that test results of confirmatory factor found there are eight indicators that have factor loading values greater than 0.5 . It is proved that these indicators can explain undimensionality latent variables. Strength of dimension in forming latent variable can be demonstrated by looking at the probability of $<0.05$ means that these indicators are significant as the dimensions of latent variables are formed. There are two indicators of exchange rate and ROA has a loading 
factor is less than 0.5, so that should be excluded from the research model. After exchange rate and efficiency ratio were excluded from the research model, the new model as follows:

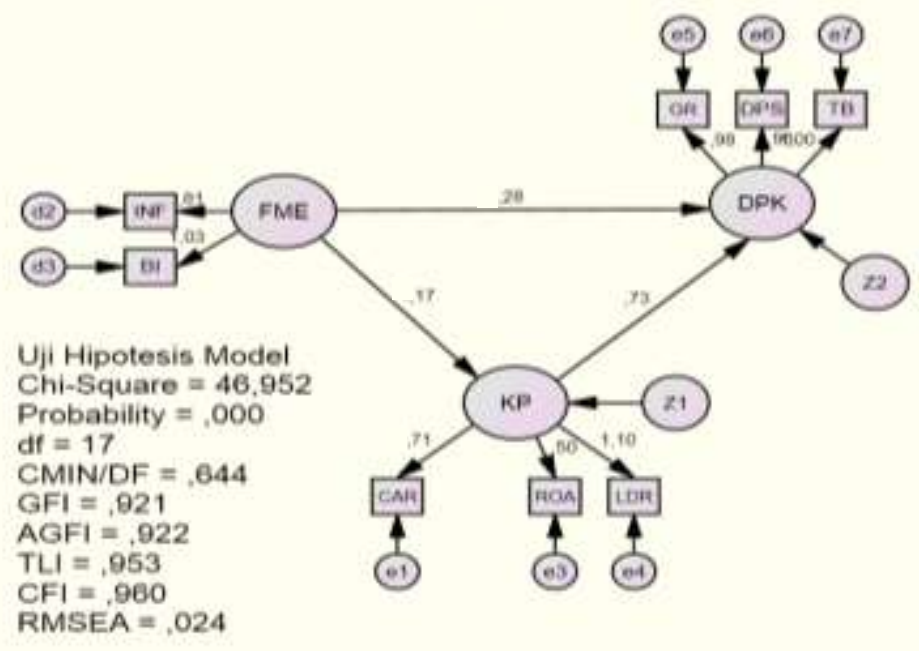

Figure 2. Last Model (Fit Model)

Source: Data Processed

Based on Figure 3 obtained the following model equation

$\begin{array}{ll}\mathrm{KP} & =0,169 \mathrm{FME} \\ \mathrm{DPK} & =0,282 \mathrm{FME} \\ \mathrm{DPK} & =0,731 \mathrm{KP}\end{array}$

Based on Figure 3 it can be seen that all recommended value according to the model. For more details criteria for a model in this study can be seen in the following table.

Table 3. Testing Goodness of Fit Model Structural Modification

\begin{tabular}{|l|c|c|c|}
\hline \multicolumn{1}{|c|}{ Goodness Of Fit Index } & Cut-off Value & Model Result & Explanation \\
\hline Chi-Square (df=17) & $\leq 27.59$ & 46.952 & Marginal \\
\hline Probability Chi-Square & $\geq 0.05$ & 0.000 & Marginal \\
\hline CMIN/DF & $\leq 2.00$ & 0.644 & Good \\
\hline RMSEA & $\leq 0.08$ & 0.024 & Good \\
\hline GFI & $\geq 0.90$ & 0.921 & Good \\
\hline AGFI & $\geq 0.90$ & 0.922 & Good \\
\hline TLI & $\geq 0.95$ & 0.953 & Good \\
\hline CFI & $\geq 0.95$ & 0.960 & Good \\
\hline
\end{tabular}

Source: Data Processed

Based on criteria evaluation of Goodness of Fit Indices in Table 3, the evaluation shows that there are two models that do not comply, then the model is acceptable. Once the model is declared fit, the next step is to analyze parameters of each indicator towards latent variables (factor loadings in AMOS declared as Standardlized Regression Weight). The model performed to analyze influence of fundamental of macroeconomy factors on bank performance and the implications to third-party funds by using eight indicators presented in Figure 3.

c) Contributions Fundamental of Macroeconomy on Performance of Banking and Third Party Funds

Contributions of indicator to latent variables can be identified from value of loading factor of each latent variables indicator used in research model. Next, it will be described value of loading factor or contributing of indicator to latent variables.

d) Hypothesis Test

\section{1) First Hypothesis Test}

The first hypothesis stated that Fundamental of Macroeconomy have a significant effect on bank performance. Based on the analysis in first hypothesis testing are presented in Table 4. 
International Journal of Advances in Scientific Research and Engineering (ijasre), Vol 7 (8), August -2021

Tabel 4. T Test Impact of Fundamental of Macroeconomy on Bank Performance

\begin{tabular}{|c|c|c|c|c|c|c|c|}
\hline \multirow{2}{*}{\multicolumn{3}{|c|}{ Variable }} & \multicolumn{2}{|c|}{ Loading Factor } & \multirow[b]{2}{*}{ S.E. } & \multirow[b]{2}{*}{ C.R. } & \multirow[b]{2}{*}{$\mathrm{P}$} \\
\hline & & & $\begin{array}{c}\text { Standardized } \\
\text { Regression Weight }\end{array}$ & Estimate & & & \\
\hline Bank Performance & & $\begin{array}{l}\text { Fundamental } \\
\text { Macroeconomy }\end{array}$ & 0.169 & 0.037 & 0.017 & 2.134 & 0.033 \\
\hline
\end{tabular}

Source: Data Processed

Table 4 shows that fundamental of macroeconomy variable has a critical ratio (CR) value greater than 2 is 2.134 , coefficient value standardized loading factor of 0.169 and p-value less than $0.05(0.033<0.05)$, so fundamental of macroeconomy influence significantly and positive to bank performance, which means that fundamental of macroeconomy improvement followed by increased banking performance, so the first hypothesis is statistically proven or accepted.

\section{2) Second Hypothesis Test}

The second hypothesis states that bank performance significantly affect third-party funds. Based on the analysis in the second hypothesis testing are presented in Table 5.

Table 5. T Test of Impact of Bank Performance to Third Party Funds

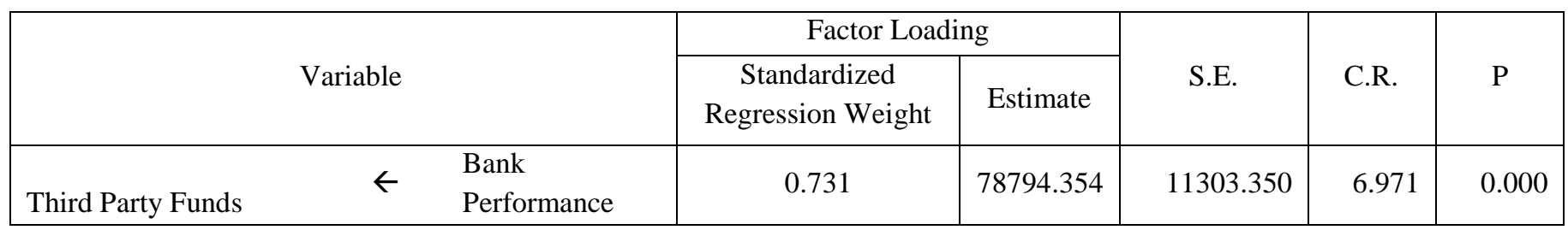

Source: Data Processed.

Table 5 shows that bank performance variable has a critical ratio (CR) value greater than 2 are 6,971, standardized coefficient value loading factor of 0.731 and p-value less than $0.05(0.000<0.05)$, so bank performance have a significant and positive impact towards third party funds, which means that increase in bank performance was followed by an increase in third party funds, so the second hypothesis is statistically acceptable.

\section{3) Third Hypothesis Test}

Third Hypothesis Test stated that Fundamental of Macroeconomy significantly affect to third party funds.

Table 6. T Test (CR) of Impact of Fundamnetal Macroeconomy to Third Party Funds

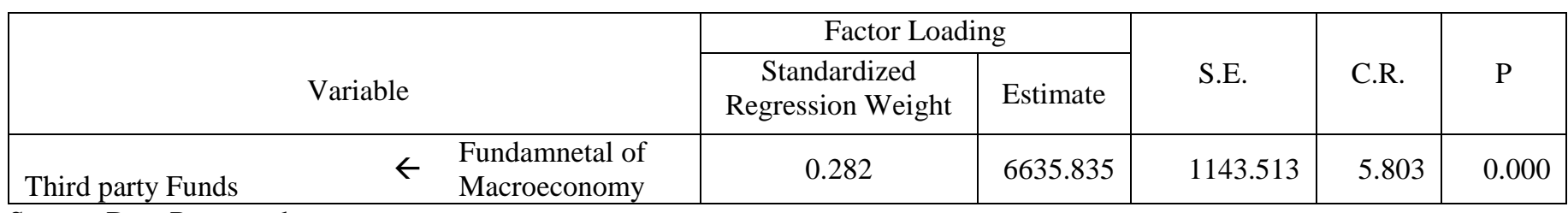

Source: Data Processed.

Table 6 shows that fundamental of macroeconomy variable has a critical ratio (CR) value greater than 2 is 5.803 , coefficient value of standardized loading factor of 0.282 and p-value less than $0.05(0.000<0.05)$, so fundamental of macroeconomy influence significantly on third party funds, thus the third hypothesis is statistically accepted.

\section{4) Fourth Hypothesis Test}

The fourth hypothesis states that Fundamental of Macroeconomy significantly affect third party funds through banking performance. Based on analysis in the fourth hypothesis testing are presented in Table 7.

Tabel 7. T Test (CR) Impact of Fundamental of Macroeconomy to Third Party Funds through Bank Performance

\begin{tabular}{|l|c|c|c|}
\hline \multicolumn{1}{|c|}{ Variable } & Direct Effect & Indirect Effect & Total Effect \\
\hline $\begin{array}{l}\text { Fundamental of Macroeconomy } \rightarrow \text { Bank Performance } \rightarrow \\
\text { Third Party Funds }\end{array}$ & 0.282 & $0.169 \times 0.731=0.123$ & 0.405 \\
\hline
\end{tabular}

Source: Data Processed.

Table 7 shows that indirect effect of fundamental of macroeconomy to third party funds via bank performance is equal to 0.123. Bank performance status as an intervening variable of the effect fundamental of macroeconomy to third-party funds. It proved by the total value greater than direct effect, thus the fourth hypothesis is statistically proven or accepted. 


\subsection{Discussion}

\section{1) The Effect of Fundamental of Macroeconomy to Bank Performance}

Fundamental of macroeconomy have significant effect on bank performance. Bank performance overall is a description of bank achievements in operational management, related to financial aspects, marketing, collection and disbursement of funds, technology and human resources. The financial performance of bank is a description of financial condition of banks in a certain period both related to collection and distribution of funds that are usually measured by indicators of capital adequacy, liquidity, and profitability. The results of this study are consistent with Suri and Danarti (2007) [8], Purwana (2009) [9], Harmono (2012) [10] and Aviliani et al (2015) [11] which stated that fundamental of macroeconomy affect bank performance.

Fundamental of Macroeconomy affect bank performance, because banks will be affected by national economy development. That is, any events which affect the real sector will affect bank performance. Economic growth will affect household incomes and consumption and ability to accumulate savings. Meanwhile, capacity of banks to finance real sector in the form of consumption and investment, among others affected by amount of public funds that have been collected as loanable funds.

Inflation is a measurement of economic activity that is also often used to describe the condition of the national economy. Inflation also can be defined as tendency of prices to rise in general and continuously (Boediono, 1985) [12]. Besides, inflation also can be interpreted as a decline in purchasing power of money (Arifin, 2002) [13]. Conditions of inflation have shown an increase in prices for some commodities or services. Prices of goods and services will decrease purchasing power, so that investment will decrease and will encourage lower interest rate. The higher inflation rate cause interest rate have tendency to decline. This is in line with research of Kanwal and Nadeem (2013) which stated that inflation is a significant effect on ROA and ROE [14].

When interest rates rise, investors will flock to sell their shares to be invested in dollars. This will lead to a decline in stock prices. Bank Indonesia (BI) will soon raise interest rates in order to prevent people prefer not to hold dollars rather than rupiah. The increasing BI rate will make a lot of people to sell their shares to be placed in the bank that can provide a higher investment rate of return. If rupiah weakened against US Dollar Exchange Rate, interest rate will tend to increase.

\section{2) The Effect of Bank Performance to Third Party Funds}

Bank performance significantly influence third party funds. Bank performance is reflected in operating profit and earnings per share as well as some financial ratios that illustrates the power of management to manage banking system. Bank performance that showed in financial statements is useful for decision makers, especially investors who invest their funds in the bank. By analyzing financial statements through calculation of financial ratios, investors can predict stock returns that are desired so that it can be made profitable portfolio of investment results.

Capital Adequacy Ratio (CAR) is a capital ratio that shows bank ability to provide funds for purpose of business development and accommodating risk of loss of funds caused by the bank operations. The higher CAR, provide greater financial resources that can be used for business development and anticipate potential losses caused by lending. CAR is very important for a bank because it show bank ability to maintain sufficient capital and ability of management to identify, measure, monitor, and control risks that arise that could affect the amount of banks capital. However, the greater CAR can reduce banks ability to expand business, growing capital reserves used to cover risk of losses. Inhibitation of business expansion due to high CAR, will affect bank financial performance. High level CAR reflects a bank that is too cautious in carrying out operations. This condition led banks tend to ignore opportunity of activities that could potentially generate a profit. Regulation that obliges CAR above $8 \%$ provide advantage of a sense of security and minimize risk of bank bankruptcy. It can affect bank profitability and increase customer confidence. However, presence these provisions make a limitation for bank strategies due to obligation to meet level of capital at a certain value. This affects revenue that may be obtained by utilizing bank with capital, not to be kept at a certain level in order to meet BI regulations, but to utilized strategy with higher returns. Banks with low CAR value will have a high cost of bankruptcy possibility. The increase CAR can reduce likelihood and increase ROA through reduced insurance costs to be incurred for banks debts were not insured.

ROA is one of financial performance measurement that is often used as basis for calculating an investor's investment. By looking at ROA, an investor will understand about company's performance.

The high LDR showe amount of financing disbursed by banks in an effort to improve operational performance. The lower LDR also showe lower bank earnings, so it will motivate banks to manage their earnings by increasing profits. LDR is used to assess bank liquidity by dividing number of loans granted by bank to deposit. The higher LDR show lower liquidity, so possibility of a bank in financial problems will be greater. Loans receivable exclude receivable from loans to the other banks. 
Third party funds are funds greatest composition and influence on bank operations. Collector of funds from public relatively easier compared to other funds. Benefit from community funds is an infinite number. Most of capital held by banks is sourced from public funds. In conducting their daily business activities, bank must have funds to provide loans to public.

\section{3) The Effect Fundamental of Macroeconomy to Third Party Funds}

Fundamental of macroeconomy significantly affect on third-party funds. When inflation increases, deposit interest rate will also be increased by bank in order to maintain liquidity. Rising interest rates will cause people unwilling to attract deposits. In addition, rising interest rates will attract people to deposit their funds in banks and expect inflation will come back down. When inflation is high then interest rates will also be high so people will earn higher interest, it is in line with research Aviliani et al. (2015) which stated that third party funds had the strongest association with almost all macroeconomy variables [11].

BI Rate as interest rate on accompanying commercial banks, either directly or indirectly has an impact on bank performance. Savings in the view of classical economics, is a function of interest rate. The high interest rates will encourage someone to save and sacrifice current consumption to be used for consumption in the future. The high interest of customers to save is affected by interest rate, this indicates that current interest rate is high, people are more interested in sacrificing current consumption in order to increase savings. BI Rate is interest rate that reflects the policy stance of monetary policy set by Bank of Indonesia and announced to public. BI Rate arises when inflation has increased. With adoption of BI as a solution to growing problem of inflation, interest rates on deposits increased and followed with interest rates on loans in order to avoid negative spread. With rising interest rates, public wants to save money in bank.

\section{4) The Effect Fundamental of Macroeconomy to Third Party Fund through Bank Performance}

Banking performance is able to mediate fundamental of macroeconomy influence on third-party funds. Fundamental of macroeconomy improvement able to create banks performance, thus encourages growth of third party funds collected from public. The higher third party funds, cause better level of public trust in banks corporate. In order to improve third-party funds, management must improve bank performance, because of better performance of banks can enhance customer confidence, so that customer will save their money in banks. Banking performance is one factor that seen by potential investors to determine their investment in bank. For banks, maintain and improve bank performance is an obligation in order to exist and attract customers. Financial statements issued by banks is a reflection of financial performance of banks. These financial statements are the end of accounting process with the aim of providing financial information to explain condition of banks in a period. The financial information has a function as a means of information, tools management accountability to bank owners, depiction of indicators of banking success, and as a material consideration in decision making.

The higher bank performance cause the higher benefit for customer. Customer always look for bank whose best performance and invest in the bank. Collection of third party fund will increase if the bank have good reputation that showed in their financial statement. Financial performance measurement include calculating financial ratios based on published and financial statement and audited by public accountant. Those ratios designed to help analyst or investors in evaluation of banks.

Inflation is an macoeconomic variable that have an impact on funds collected by baks. Increasing inflation rate cause government increase BI Rate and have an impact on increasing interest rate of saving and credit. Increasing interest rate of saving will increase people willingness to save their funds in bank. Increasing BI rate have an impact on increasing interest rate of savings.

\section{CONCLUSION AND SUGGESTION}

\subsection{Conclusion}

This research aimed to describe fundamental of macroeconomy, banking performance and third party funds, analyze the impact fundamental of macroeconomy to banking performance, analyze the impact of banking performance to third party funds, analyze the impact of fundamental of macroeconomy to third party funds, and analyze the impact of fundamental of macroeconomy to third party funds through banking performance. Based on the analysis and discussion, it can conclude as follows:

a. Fundamental of macroeconomy formed by exchange rate of rupiah to US dollar, inflation and BI rate. Fluctuation in exchange rate, inflation BI rate depend on internal factors nationally, such as increasing petroleum price, and also external factors such as US's exchange rate policy and global economy. Banking performance measured by CAR, ROA, efficiency ratio and LDR. Banking performance in Indonesia were in health category, although it have been inefficient. Their capability to generate profit from their assets were better but they still conservative in provide credit. Third party funds collected in period 2004 - 2014 tend to increase. 
b. Fundamental of macroeconomy affect to banking performance, it indicate that every events related to inflation and BI rate in real sector will affect to benking performance. The alteration in fundamental of macroeconomy affect to people income and their consumption capability and accumulate saving fund. These are in line with research of Suri and Danarti (2007), Purwana (2009), Harmono (2012) and Aviliani et al (2015) stated that macroeconomy conditions affect to banking performance.

c. Banking performance affect to third party funds. Increasing interest rate will stress growth of third party funds, include bank's assets. Banking performance that reported in financial statements provide advantage for decision maker, especially for investors to invest their funds in bank. Bank capacity to finance real sector, both in form of consumption or investment credit influenced by the amount of collected third party funds.

d. Fundamental of macroeconomy influence third party funds. When inflation increase, interest rate of savings will increased by bank to keep liquidity. The higher inflation cause the higher interest rate so customer will get the higher interest revenue. The high interest rate encourage customer to increase their savings and decrease their consumption.

e. Banking performance that are capital adequacy ratio, return on assets and loan to deposit ratio as mediator of fundamental of macroeconomy reflected by inflation and BI rate to increase third party funds. It indicate that banking performance will considered by customer to save their funds in bank. The increasing interest rate will increase customer willingness to invest in bank.

\subsection{Suggestion}

1) For the banks, suggested to collect more funds from third party with advanced study to maximize sources of third party funds. Bank must increase people trust of performance, capability, integrity adnd credibility of banks. In addition, bank must ensure safety, service, management and expectation of revenue that customer will got from their funds saved. Bank also must to keep in health category.

2) For communities, this research may help customer to understand banking performance related to bank's function as the intermediary institution in investment considering.

3) For science development, give a boarder development of economics, especially financial performance concept that not only influenced by fundamental of macroeconomy and its implication to third party funds. It may give a basic evidence to model development related to monetary policy.

4) For the next researcher, suggested to take a study in another industry with a wider sample and use a difference ratios in a boarder observation and recent data to take a complete conclusion and comprehensive understanding of this concept.

\section{REFERENCES}

1.Rose, Peter S. 2002. Commercial Bank Management, Fifth Edition. Mc-Graw-Hill Irwin.

2. Friday. 2006. Analysis of Financial Statements. Jakarta: Earth Literacy.

3. Samuelson, Paul A. and William D. Nordhaus, 2001. Macro-economics, $17^{\text {th }}$ Edition. Mc-Graw-Hill Higher Education.

4. Stiglitz, Joseph E. and Carl E Walsh. 2006. Economics. 4th ed. New York: W.W. Norton.

5. Cashmere. 2003. Analysis of Financial Statements. Press Eagle. Jakarta.

6. Suyatno, Thomas. 1999. Banking Institutions. PT Library Gramedia. Jakarta.

7. Dendawijaya, Lukman. 2009. Banking Management, Jakarta: Ghalia Indonesia.

8. Suri, Datu Asmira and Tyas Danarti. 2007. Effect of Credit Distribution on Bank Capital (Case Study of Bank Permata Malang Branch 2002:1 - 2005:4). http://google.com

9. Purwana, Edward Gagah. 2009. Analysis of the Effect of Capital Adequacy Ratio (CAR), Loan To Deposit Ratio (LDR), Size, BOPO on Profitability (Comparative Study of Domestic Banks and Foreign Banks Period January 2003-December 2007), http://eprints.undip.ac.id/29479/

10. Harmony. 2012. Analysis of Macro Fundamental Factors, Credit Interest Scheme as Intervening Variables Its Effect on Company Performance, Financial Journal and Banks, Accredited by DIKTI. ISSN:1410-8089.

11. Aviliani, Hermanto Siregar, Tubagus Nur Ahmad Maulana and Heni Hasanah. 2015. The Impact of Macroeconomic Condition on The Bank's Performance In Indonesia. Bulletin of Monetary, Economics and Banking, Volume 17, Number 4, April: 379-402.

12. Boediono, 2014, Monetary Economics. Issue 3. BPFE. Yogyakarta.

13. Arifin, Zainul. 2002. Fundamentals of Islamic Bank Management. Jakarta: AlvaBet.

14. Kanwal, Sara and Muhammad Nadeem. 2013. The Impact of Macroeconomic Variables on The Profitability of Listed Commercial Banks In Pakistan. European Journal of Business and Social Sciences, Vol. 2, No.9:186-201.

Corresponding author: iqbal_firdausi@yahoo.co.id 